\title{
Bevoegd én bekwaam
}

\section{Wim Otto}

Sommige dingen zijn niet ingewikkeld, maar moet je gewoon doen. Dat gevoel bekruipt mij als ik het artikel van Claudia Maria Greijn, et al. lees. Bijwonen van elkaars spreekuren en het gebruiken van beeldopnames om te leren van elkaars vaardigheden. Helaas nog geen 'gewoonste zaak van de wereld' binnen onze beroepsgroepen. Veel aios, die in het kader van hun opleiding beeldopnames van hun eigen spreekuur aan anderen ter beoordeling voorleggen, zien dat anders. Je krijgt inzicht in wat je beter kunt doen en je doet inspiratie op door te zien hoe collega's hun gesprekken voeren. Niet slechts van belang om je bevoegdheid te behouden, maar een wezenlijke en voortdurende leeractiviteit om je bekwaamheid op peil te houden en waar mogelijk te vergroten.

Elkaar beoordelen als onderdeel van en gezamenlijk streven naar constante kwaliteitsverbetering is van geheel andere orde dan de beoordelingen die in het kader van de zogeheten RIV-toets plaatsvinden (RIV = re-integratieverslag). Tot welke, in mijn ogen, bizarre situatie dat kan leiden wordt duidelijk in één van de twee tuchtzaken die in dit $T B V$ worden besproken. Bedrijfsarts klaagt verzekeringsarts aan vanwege diskwalificerende opmerking. Wat we hier zien is dat het wettelijk kader ertoe kan leiden dat bedrijfs- en verzekeringsartsen elkaar met argusogen gaan bekijken in plaats van zo veel mogelijk samen optrekken om het belang van de cliënt te dienen.

De positie van de bedrijfsarts lijkt mij daarbij het lastigst. Zijn onafhankelijkheid staat onder druk door zijn opdrachtnemersrelatie met de werkgever. Juist door gedurende de eerste twee jaar van arbeidsongeschiktheid de samenwerking met de verzekeringsarts te zoeken kan de bedrijfsarts zijn positie in relatie tot de werkgever verstevigen en zich onafhankelijk opstellen zonder daar nadeel van te ondervinden. Hij weet zich immers verzekerd van de rugdekking door de verzekeringsarts. Dat is echter alleen mogelijk als verzekeringsartsen een goede balans weten te vinden tussen hún onafhankelijke positie en meer directe betrokkenheid bij begeleiding en beoordeling in de eerste twee jaar. Een uitdaging voor beide beroepsgroepen in het belang van de cliënt.

Ook vakinhoudelijk heeft dit $T B V$ weer veel te bieden. Twee onderwerpen licht ik er voor $u$ uit.

In de eerste plaats de twee bijdragen over kanker van Jan-Willem Koten, in samenwerking met André Weel. Hij heeft voor ons de nieuwste inzichten in de carcinogenese op een rij gezet en wat dat betekent voor de ontwikkelingen in de kankertherapie. Relevante informatie voor de dagelijkse praktijk, die navolging verdient door vaker een 'klinisch' onderwerp te behandelen.

In de tweede plaats wil ik uw aandacht vestigen op de bespreking van het proefschrift van Evelien van Valen. Met haar onderzoek heeft zij een internationale norm neergezet voor de neuropsychologische diagnostiek van CSE (chronic solvent-induced encephalopathy) ofwel de schildersziekte.

Minder bekend wellicht is het verband tussen blootstelling aan oplosmiddelen en systeemsclerose. Daarvoor komt steeds meer bewijs, aldus Ellen De Langhe.

Tot slot. Iris Homeijer is nog niet zo lang bestuurslid (en vicevoorzitter) van de NVAB en vraagt zich in haar column af of er wel wat te besturen valt. Na een bestuurservaring met paarden dringt die gedachte zich bij haar op. Zonder de inbreng van de leden is het lastig besturen. Stiekem denk ik: dat geldt ook voor het maken van $T B V$. Laat weten hoe je erover denkt en wat je beroepsvereniging of vaktijdschrift voor je kan betekenen. Je kunt mailen naar TBVredactie@bsl.nl. 